\title{
Note
}

\section{A Review and the Conservation Implications of Aquatic Behaviour and Drowning in Jumping Mice (Dipodidae: Zapodinae)}

\author{
JENNIFER K. FREY
}

Department of Fish, Wildlife and Conservation Ecology, New Mexico State University, Las Cruces, New Mexico 88003 USA; email: jfrey@nmsu.edu

Frey, Jennifer K. 2017. A review and the conservation implications of aquatic behaviour and drowning in jumping mice (Dipodidae: Zapodinae). Canadian Field-Naturalist 131(2): 141-143. https://doi.org/10.22621/cfn.v131i2.1869

Jumping mice (Dipodidae: Zapodinae) have a generalized terrestrial quadrupedal locomotion with specializations for saltatory and scansorial locomotion. I reviewed first-hand accounts of aquatic behaviour in the literature and confirmed that jumping mice are semi-aquatic, using both primitive quadrupedal paddling on the surface as well as the more derived simultaneous bipedal pelvic paddling while swimming underwater. Although proficient swimmers, jumping mice are also prone to drowning, especially in human-made pools. Management of populations of jumping mice with conservation concern should consider potential hazards faced by jumping mice in an aquatic environment.

Key Words: Endangered species; jumping mouse; Eozapus; Zapus; Napaeozapus; pitfall trap

\section{Introduction}

The jumping mice (Dipodidae: Zapodinae) include four North American species, Meadow Jumping Mouse (Zapus hudsonius), Pacific Jumping Mouse (Zapus trinotatus), Western Jumping Mouse (Zapus princeps), and Woodland Jumping Mouse (Napaeozapus insignis), all found in Canada (Banfield 1974), and one palearctic species, Chinese Jumping Mouse (Eozapus setchuanus; Wilson and Reeder 2005). The Zapodinae are generalized quadrupeds, but they are the sister taxon to the more specious jerboas (Dipodinae, Allactaginae, Cardiocraniinae, and Euchoreutinae), which are highly specialized for arid environments and use highly derived bipedal locomotion (Lebedev et al. 2012).

All species of jumping mice are commonly associated with wet habitats and are frequently found along streams and rivers or in marshes, swamps, and other freshwater wetlands (Krutzsch 1954). Consequently, an ability to swim might be a valuable adaptive trait for life in these environments. However, jumping mice are considered to have a generalized terrestrial quadrupedal mode of locomotion with some morphological specialization for saltatory and scansorial locomotion (Samuels and Van Valkenburgh 2008; Wright and Frey 2014). Other than somewhat small external pinnae with an antitragal flap, which can cover the external auditory meatus, and reduced size of testes and scrotum, jumping mice lack many of the specialized adaptations often found in semi-aquatic small mammals, such as interdigital webbing or fringes, dense non-wettable underfur, laterally compressed tail, valvular nares, and nictitating membranes (Krutzsch 1954).

Because of their association with fragile and declining wetland habitats, some populations of jumping mice are of conservation concern, and two forms (Zapus hudsonius preblei and Z. h. luteus) are now listed under the United States Endangered Species Act (Malaney and Cook 2013; USFWS 2014). Although no jumping mice have been assessed by the Committee on the Status of Endangered Wildlife in Canada (SARA Public Registry 2017), it is important to understand more clearly the behavioural relation of jumping mice with water, which is a frequent component of their habitat. For instance, some endangered populations of jumping mice occur in irrigated valleys where human-constructed canals and ditches convey water and could pose barriers to jumping mice if they are poor swimmers (e.g., Wright and Frey 2015). Thus, the purpose of this report was to review existing, first-hand information about aquatic behaviour in jumping mice (swimming or drowning) and to evaluate the conservation implications of that information.

\section{Methods}

I searched for published, first-hand observations of aquatic behaviour in jumping mice. Search terms included: Zapus, Napaeozapus, Eozapus, aquatic, swim, swam, swimming, drown, drowned, and drowning. Search engines included: Google Scholar, Google Books, and Web of Science. I categorized accounts of swimming by species and by nature of the observation (i.e., free-ranging animals or animals forced to swim in laboratory or natural water body). I categorized accounts of drowning by species and the type of water body (i.e., natural or artificial). Quotes and references to first-hand observations of swimming and drowning are detailed in supplementary material Appendices S1 and S2, respectively.

\section{Results and Discussion \\ Swimming}

I found 18 papers that described swimming behaviour in Zapodinae (Appendix S1). Of the observations where the species was identified, 13 were of $Z$. hudsonius, three were of $Z$. princeps, and three were $N$. insignis; no information about aquatic behaviour was

A contribution towards the cost of this publication has been provided by the Thomas Manning Memorial Fund of the Ottawa Field-Naturalists' Club. 
found for Eozapus. Most of the reports were anecdotal observations of free-ranging animals. Four accounts were of animals forced to swim: Quimby (1951) observed five $Z$. hudsonius that were taken out into a lake and observed from a boat; Whitaker (1963) forced two $Z$. hudsonius to swim, although it was not stated where the observation occurred; Dagg and Windsor (1972) recorded data from a $Z$. hudsonius forced to swim in an aquarium; and Wrigley (1972) observed a $N$. insignis forced to swim in an aquarium.

Although swimming behaviour in jumping mice has not been rigorously tested, these first-hand accounts of swimming behaviour allow some conclusions to be made. Jumping mice enter water both accidentally (e.g., following an erratic jump when frightened) and intentionally. Jumping mice are capable of swimming on top of water, underwater, and against a current. Most observers thought that the jumping mice swam with ease and relatively swiftly. Duration of swimming was up to about 5 minutes. Jumping mice swam underwater for up to about 1 minute before surfacing for air. Underwater swimming usually occurred about $10-30 \mathrm{~cm}$ below the surface, but up to about $45 \mathrm{~cm}$ below the surface.

In parallel with their dual quadrupedal and saltatory modes of terrestrial locomotion, jumping mice exhibit two major modes of swimming. In all cases propulsion is via the limbs, and the elongated hindlimbs, feet, and toes, which are normally adaptations associated with saltatory locomotion (Banfield 1974), serve double duty as powerful swimming devices. On the surface, jumping mice may swim via quadrupedal paddling, which involves alternate use of both limbs in a vertical plane, as typified by a Dog (Canis familiaris; Fish 1996). This is considered the most primitive form of drag-based swimming propulsion, and it is used by both terrestrial and semi-aquatic mammals(Fish 1996). However, jumping mice were more frequently observed using simultaneous pelvic paddling, especially when swimming underwater. In this mode, which is used by more derived semi-aquatic mammals, such as the River Otter (Lontra canadensis), propulsion is via simultaneous strokes of the hind limbs (Fish 1996). Surface swimming is energy inefficient because of the increased drag at the surface (i.e., wave drag). Because wave drag increases with speed, the relatively slow quadrupedal paddling economizes energy expenditures when swimming on the surface. However, underwater bipedal paddling offers greater energy efficiency and speed. The optimum depth for reducing wave drag is greater than three body diameters, which is consistent with observations of jumping mice swimming about $10-30 \mathrm{~cm}$ underwater (Fish 1996).

Although bipedal paddling is relatively efficient because it reduces interference from the other limbs, $N$. insignis was also observed to use simultaneous pelvic paddling in conjunction with simultaneous pectoral paddling when swimming on the surface (Wrigley 1972). In this mode, the forelimbs stroked as the hind limbs were brought up to the body, which was followed by the propulsive stroke of the hind limbs. Thus, the limb motions resembled the saltatory hop on land. The overall effect of a swimming jumping mouse using this mode was a dorsal rocking motion that created an audible rhythmic splashing in time with the strokes. Presumably the actions of the forelimbs helped keep the head above water during this more vigorous surface swimming mode.

Jumping mice can transition from surface swimming to underwater swimming by diving. Although most mammals can swim, underwater swimming is uncommon and is generally limited to species that live in close association with water (Dagg and Windsor 1972). When jumping mice are swimming underwater, air is apparently trapped by the fur, which makes the animals appear silvery. However, Wrigley (1972) reported that the pelage of $N$. insignis did not hold air as well as that of deer mice (Peromyscus) and, thus, provided less buoyancy. Dagg and Windsor (1972) reported that $Z$. hudsonius swam horizontally on the surface of the water with its back submerged (in contrast with animals with dense fur, which allows them to float with their backs above water) and that, as the fur became wetted and they lost buoyancy, their body position shifted to a $25^{\circ}$ angle to the water surface.

The tail is not used in swimming, either for propulsion or as a rudder, as it either drags behind limply or is carried arched up in the middle. In other semi-aquatic mammals, the tail is often laterally compressed; however, the tail of jumping mice is narrow and roundish in cross section providing relatively little surface area. Swimming jumping mice are able to steer purposefully to travel to specific points; the exact mechanism for steering is unknown but presumably is similar to that of other semi-aquatic rodents (Fish et al. 2002).

\section{Drowning}

I found 11 accounts of jumping mice drowning: ten free-ranging $Z$. hudsonius and one captive neonatal $N$. insignis (Appendix S2). All instances of drowning in free-ranging $Z$. hudsonius where the nature of the water body could be determined $(n=8)$ were in small artificial pools of liquid that acted as pitfall traps: milk pan, water tub, post hole, fish hatchery pond, pitfall traps filled with water, goldfish pond, plastic sheeting filled with rain water, plastic wading pool. It seems likely that jumping mice inadvertently enter these pools, perhaps as a result of their jumping behaviour or via scansorial locomotion in overhanging vegetation. However, they were unable to escape because of steep or slick walls and relatively deep fluid that prevents effective jumping.

\section{Conservation implications}

Jumping mice are semi-aquatic and capable of both surface and more advanced underwater swimming. Thus, small bodies of water likely do not represent barriers to them, and small streams may provide important escape habitat. However, jumping mice appear to tire of swimming after several minutes, which would limit their ability to cross larger bodies of water. 
Although capable swimmers, jumping mice also seem to be particularly vulnerable to drowning in both natural and human-constructed pools of liquid, such as post holes, goldfish ponds, and fish hatchery runs. Compared with other small mammals, jumping mice may be more vulnerable to drowning in pools because of their normal modes of locomotion and escape behaviours; they may inadvertently enter pools, including artificial above-ground pools, through their saltatory locomotion or via their scansorial climbing in overhanging vegetation (Wright and Frey 2014). Further, the normal escape behaviour of a frightened jumping mouse consists of a few erratic ricochetal hops followed by an abrupt stop and remaining motionless (Whitaker 1963). However, a ricochetal hop may not be possible if the mouse is in water that is too deep or it may be ineffective if the pool sides are too close or steep to allow escape. It is also possible that steep or slippery sides preclude jumping mice from climbing out of pools. Jumping mice appear to be particularly vulnerable to capture in pitfall traps (Williams and Braun 1983; Handley and Kalko 1993; Kalko and Handley 1993; Murphy et al. 2007). Augmentation of water-filled pitfall traps with slabs of wood still resulted in large numbers of dead rodents, including Zapus (Murphy et al. 2007), although it is unknown to what extent addition of other structures in pitfall traps (e.g., sticks, strings) could facilitate escape by jumping mice while also retaining target species, such as amphibians.

Thus, because pitfall traps or plastisc reptile cover sheets can partly fill with water or rain, they should not be used in areas with vulnerable populations of jumping mice. Smooth, steep-sided canals and ditches also might pose a drowning hazard. Some techniques used for fish sampling or angling, such as electrofishing or submerged minnow traps, may be a concern in areas occupied by vulnerable populations of jumping mice. Management of vulnerable populations should consider potential impacts of large aquatic predators such as American Bullfrog (Lithobates catesbeianus), Brown Trout (Salmo trutta), and black bass (Micropterus spp.), which could target swimming jumping mice as prey.

\section{Literature Cited}

Banfield, A. W. F. 1974. The Mammals of Canada. University of Toronto Press, Toronto, Ontario, Canada.

Dagg, A. I., and D. E. Windsor. 1972. Swimming in northern terrestrial mammals. Canadian Journal of Zoology 50: 117130. https://doi.org/10.1139/z72-019

Fish, F. E. 1996. Transitions from drag-based on lift-based propulsion in mammalian swimming. American Zoologist 36: 628-641. https://doi.org/10.1093/icb/36.6.628

Fish, F. E., J. Smelstoys, R. V. Baudinette, and P. S. Reynolds. 2002. Fur does not fly, it floats: buoyancy of pelage in semi-aquatic mammals. Aquatic Mammals 28: 102-112.

Handley, C. O., Jr., and E. K. V. Kalko. 1993. A short history of pitfall trapping in America, with a review of methods currently used for small mammals. Virginia Journal of Science 44: 19-26.

Kalko, E. K. V., and C. O. Handley, Jr. 1993. Comparative studies of small mammal populations with transects of snap traps and pitfall arrays in southwest Virginia. Virginia Journal of Science 44: 3-18.

Krutzsch, P. H. 1954. North American jumping mice (genus Zapus). University of Kansas Publications, Museum of Natural History 7: 349-472. Accessed 31 August 2017. http: //www.gutenberg.org/files/40110/40110-h/40110-h.htm.

Lebedev, V. S., A. A. Bannikova, M. Pages, J. Pisano, J. R. Michaux, and G. I. Shenbrot. 2012. Molecular phylogeny and systematics of Dipodoidea: a test of morphologybased hypotheses. Zoologica Scripta 42: 231-249. https:// doi.org/10.1111/zsc. 12002

Malaney, J. L., and J. A. Cook. 2013. Using biogeographic history to inform conservation: the case of Preble's meadow jumping mouse. Molecular Ecology 22: 6000-6017. https://doi.org/10.1111/mec. 12476

Murphy, R. K., R. A. Sweitzer, and J. D. Albertson. 2007. Occurrences of small mammal species in a mixed-grass prairie in northwestern North Dakota. Prairie Naturalist 39: 91-95.

Quimby, D. C. 1951. The life history and ecology of the jumping mouse, Zapus hudsonius. Ecological Monographs 21: 61-95. https://doi.org/10.2307/1948646

Samuels, J. X., and B. Van Valkenburgh. 2008. Skeletal indicators of locomotor adaptations in living and extinct rodents. Journal of Morphology 269: 1387-1411. https:// doi.org/10.1002/jmor.10662

SARA (Species at Risk Act) Public Registry. 2017. Species at risk public registry. Government of Canada, Ottawa, Ontario, Canada. Accessed 20 June 2017. http://sararegis try.gc.ca/default.asp?lang=En\&n=24F7211B-1

USFWS (United States Fish and Wildlife Service). 2014. Determination of endangered status for the New Mexico meadow jumping mouse throughout its range. Final rule. Federal Register 79: 33119-33137.

Whitaker, J. O., Jr. 1963. A study of the meadow jumping mouse, Zapus hudsonius (Zimmerman), in central New York. Ecological Monographs 33: 215-254. https://doi.org $/ 10.2307 / 1942627$

Williams, D. F., and S. E. Braun. 1983. Comparison of pitfall and conventional traps for sampling small mammals. Journal of Wildlife Management 47: 841-845.

Wilson, D. E., and D. M. Reeder. 2005. Mammal Species of the World: A Taxonomic and Geographic Reference. Third edition. Johns Hopkins University Press, Baltimore, Maryland, USA.

Wright, G. D., and J. K. Frey. 2014. Herbeal feeding behavior of the New Mexico meadow jumping mouse (Zapus hudsonius luteus). Western North American Naturalist 74: 231-235. https://doi.org/10.3398/064.074.0210

Wright, G. D., and J. K. Frey. 2015. Habitat selection by the endangered New Mexico meadow jumping mouse (Zapus hudsonius luteus) on an irrigated floodplain. Journal of Fish and Wildlife Management 6: 112-129. https: //doi.org/10.3996/062014-JFWM-044

Wrigley, R. E. 1972. Systematics and Biology of the Woodland Jumping Mouse, Napaeozapus insignis. University of Illinois Press, Chicago, Illinois, USA.

Received 25 October 2016

Accepted 20 June 2017

\section{SuPPlementary Material:}

APPENDIX S1: First-hand accounts of swimming behaviour in the Zapodinae.

APPENDIX S2: First-hand accounts of drowning in the Zapodinae. 